\title{
PENGARUH LAMA PERENDAMAN DALAM LARUTAN NACL DAN LAMA PENGERINGAN TERHADAP MUTU TEPUNG TALAS BELITUNG (Xanthosoma sagittifolium)
}

\author{
[The Effect of NaCl Soaking Time and Drying Time on The Quality of Belitung Taro Flour \\ (Xanthosoma sagittifolium)]
}

Suci Suharti ${ }^{*}$, Ahmad Alamsyah dan Yeni Sulastri

Program Studi Ilmu dan Teknologi Pangan, Fakultas Teknologi Pangan dan Agroindiustri, Universitas Mataram *Email: Suci suharti@ymail.com

Diterima 10 April 2019 / Disetujui 22 Mei 2019

\begin{abstract}
The purpose of this study was to determine the effect of $\mathrm{NaCl}$ soaking time and drying time on the quality of belitung taro flour (Xanthosoma sagittifolium). This study used a factorial design using 2 factors: $\mathrm{NaCl}$ soaking time (0,30, and 60 minutes) and drying time (3,4 and 5 hours) consisting of 9 treatments and 3 replications. The parameters observed included chemical parameters (moisture, ash, starch, calcium oxalate, and crude fiber content) and physical parameters (yield, bulk density and color value $L *$ ). The results of the research data were analyzed using analysis of variance alpha 5\% and if there were significant differences it was tested further using the Duncan Multiple Range Test. The results showed that the treatment of soaking time in NaCl solution had a significantly effect on chemical parameters (moisture, ash, starch, calcium oxalate, and crude fiber content) and physical parameters (yield, bulk density, color value $L^{*}$ ). The drying time gave significantly effects on chemical parameters (moisture, ash, starch, calcium oxalate, and crude fiber content) and physical parameters (yield and bulk density). The interaction between $\mathrm{NaCl}$ soaking time and drying time gave a significantly effect on calcium oxalate content. The best treatment is 60 menit NaCl soaking time and 5 hours drying time (L3P3) with $3.56 \%$ moisture, $1.31 \%$ ash, $64.36 \%$ starch, $337.82 \mathrm{mg} / 100 \mathrm{~g}$ calcium oxalate, $2.5 \%$ crude fiber content, $19.31 \%$ yield, $0.71 \mathrm{~g} / \mathrm{ml}$ bulk density, and $\mathrm{L}^{*}$ color value 92.28 that has met the SNI quality requirements for cassava flour.
\end{abstract}

Keywords: belitung taro, drying time, flour, NaCl, soaking time

\section{ABSTRAK}

Tujuan penelitian ini adalah untuk mengetahui pengaruh lama perendaman dalam larutan $\mathrm{NaCl}$ dan lama pengeringan terhadap mutu tepung talas belitung (Xanthosoma sagittifolium). Penelitian ini menggunakan Rancangan Faktorial menggunakan 2 faktor yaitu faktor lama perendaman dalam larutan $\mathrm{NaCl}(0,30$, dan 60 menit) dan faktor lama pengeringan ( 3,4 dan 5 jam) yang terdiri dari 9 perlakuan dan 3 ulangan. Parameter yang diamati meliputi parameter kimia (air, abu, pati, kalsium oksalat, dan kadar serat kasar) dan parameter fisik (rendemen, densitas kamba dan warna nilai $\mathrm{L}^{*}$ ). Data hasil penelitian dianalisis menggunakan analisis keragaman pada taraf nyata $5 \%$ dan apabila terdapat beda nyata maka diuji lanjut menggunakan uji Duncan Multiple Range Test. Hasil penelitian menunjukkan bahwa perlakuan lama perendaman dalam larutan $\mathrm{NaCl}$ memberikan pengaruh yang berbeda nyata terhadap parameter kimia (kadar air, abu, pati, kalsium oksalat, dan serat kasar) dan parameter fisik (rendemen, densitas kamba, warna nilai L*). Perlakuan lama pengeringan memberikan pengaruh yang berbeda nyata terhadap parameter kimia (air, abu, pati, kalsium oksalat, dan kadar serat kasar) dan parameter fisik (rendemen dan densitas kamba). Interaksi antara lama perendaman dalam larutan $\mathrm{NaCl}$ dengan lama pengeringan memberikan pengaruh yang berbeda nyata terhadap kadar kalsium oksalat. Perlakuan terbaik yaitu lama perendaman dalam larutan $\mathrm{NaCl} 60$ menit dan lama pengeringan 5 jam atau L3P3 dengan kadar air 3,56\%, abu 1,31\%, pati 64,36\%, kalsium oksalat $337,82 \mathrm{mg} / 100 \mathrm{~g}$, serat kasar 2,5\%, rendemen $19,31 \%$, densitas kamba $0,71 \mathrm{~g} / \mathrm{ml}$, dan warna nilai L* 92,28 yang telah memenuhi syarat SNI mutu tepung singkong.

Kata Kunci: lama perendaman, lama pengeringan, $\mathrm{NaCl}$, talas belitung, tepung

\section{PENDAHULUAN}

Pangan merupakan kebutuhan dasar bagi manusia yang terus meningkat seiring dengan peningkatan jumlah penduduk. Berbagai jenis pangan diproduksi dengan meningkatkan kuantitas serta kualitasnya untuk memenuhi kebutuhan pangan masyarakat. Salah satu upaya untuk memenuhi kebutuhan pangan dan penyediaan pangan dapat dilakukan dengan meningkatkan budidaya dan pemanfaatan hasil pertanian seperti umbi-umbian. Dari beberapa umbiumbian yang ada di Nusa Tenggara Barat 
khususnya pulau Lombok, talas belitung (Xanthosoma sagittifolium) merupakan salah satu umbi-umbian yang banyak ditanam dengan biaya yang relatif murah namun penggunaannya masih terbatas. Umumnya talas hanya dimanfaatkan sebatas umbi segarnya saja yang diolah dengan cara direbus, disayur, digoreng dan dibuat kripik.

Talas belitung merupakan tanaman penghasil karbohidrat yang tinggi yang memiliki peranan cukup baik. Kendala pengolahan talas belitung sebagai bahan pangan adalah adanya kandungan oksalat sebesar 1. $740 \mathrm{mg} / 100 \mathrm{~g}$ (Hardiati, 2014), sedangkan pada talas bogor sebesar 11,2292 mg/100 gr (Purwaningsih dan Kuswiyanto, 2016) atau 8578,28 ppm (Mayasari, 2010). Batas aman konsumsi kalsium oksalat bagi orang dewasa adalah $0,60-1,25 \mathrm{~g}$ per hari selama 6 minggu berturut-turut (Knudsen et al., 2008). Proses pencernaan kalsium oksalat dapat mengakibatkan korosi pada mulut dan sistem pencernaan serta gagal ginjal. Gejala pada pencernaan yaitu abdominal kram dan muntah- muntah yang dengan cepat diikuti kegagalan peredaran darah dan pecahnya pembuluh darah inilah yang dapat menyebabkan kematian (Mariani, 2008), sehingga memerlukan penanganan agar kandungan oksalat pada talas dapat direduksi. Salah satu cara untuk mereduksi oksalat adalah dengan perendaman talas di dalam larutan $\mathrm{NaCl}$. Natrium klorida $(\mathrm{NaCl})$ juga disebut dengan garam dapur adalah zat yang memiliki tingkat osmotik yang tinggi. $\mathrm{NaCl}$ yang terlarut dapat meningkatkan konsentrasi air sehingga memecahkan dinding vakuola umbi talas. Menurut Mayasari (2010), perendaman umbi talas bogor dalam larutan garam $\mathrm{NaCl} 10 \%$ selama 60 menit dapat mereduksi oksalat sebesar 93,62\%. Dengan tereduksinya kandungan oksalat pada talas maka akan menghasilkan sumber pangan yang dapat dijadikan sebagai alternatif pangan Indonesia (Marliana, 2011).

Umbi talas belitung mengandungan $63,1 \%$ air dengan karbohidrat 34,2\% (Lingga, 1989). Karbohidrat pada umbi talas sebagian besar merupakan komponen pati, sedangkan komponen lainnya adalah pentosa, serat kasar, dekstrin, sukrosa dan gula pereduksi (Onwueme, 1978). Talas memiliki potensi untuk dapat digunakan sebagai bahan baku tepung-tepungan karena memiliki kandungan pati yang tinggi, yaitu sekitar $70-80 \%$. Tepung talas memiliki ukuran granula pati yang kecil, yaitu sekitar 0.5-5 mikron (Koswara, 2010). Untuk membuat tepung talas harus dilakukan dengan kondisi pengeringan yang tepat. Pengeringan adalah suatu cara mengurangi kadar air suatu barang, sehingga diperoleh hasil akhir yang kering. Dengan mengurangi kadar airnya, bahan pangan akan mengandung senyawa seperti protein, karbohidrat, lemak, dan mineral dalam konsentrasi yang lebih tinggi (Almatsier, 2010). Pengeringan ini bertujuan untuk memperpajang masa simpan bahan pangan. Penelitian tentang tepung talas belitung telah dilakukan oleh Indrasti (2004) dimana proses pengeringan menggunakan oven pada suhu $60^{\circ} \mathrm{C}$ selama 5 jam, kemudian digiling dan diayak dengan ayakan 60 mesh. Penelitian tersebut menghasilkan tepung talas belitung dengan kadar air 9,22\%, kadar abu 1,94\%, kadar protein 4,43\%, kadar lemak 0,84\%, kadar karbohidrat $83,57 \%$, derajat putih $73,73 \%$ dan energi 359,56 kkal per 100 gram. Tingginya kandungan karbohidrat dalam tepung talas belitung diharapkan mampu membuat tepung talas belitung menjadi bahan pangan sumber karbohidrat yang murah, selain itu rendahnya nilai kandungan lemak yang terdapat dalam tepung talas belitung membuat tepung talas belitung menjadi tidak mudah rusak atau tengik, sehingga dapat disimpan dalam waktu yang lama, dan tepung talas belitung bebas dari gluten. Ketiadaan gluten pada tepung talas belitung membuat tepung talas belitung dapat digunakan sebagai diet bagi penderita autis (Winarno dan Agustinah, 2008).

Pembuatan tepung talas belitung juga dilakukan oleh Ridal (2003) dimana pada proses pengeringan talas belitung menggunakan oven pada suhu $50-60^{\circ} \mathrm{C}$ selama 6 jam. Proses tersebut menghasilkan tepung talas belitung dengan kadar air 6,20\%, kadar abu $1,28 \%$, kadar serat 2,16\%, kadar protein $0,69 \%$, kadar lemak $1,25 \%$, kadar 
Versi Online:

http://Www.profood. unram.ac.id/index.php/profood e-ISSN: 2443-3446

amilosa $16,29 \%$, kadar pati $70,73 \%$, suhu awal tergelatinisasi $79^{\circ} \mathrm{C}$, absorbansi awal $2,57 \mathrm{~g} / \mathrm{g}$, absorbansi minyak $2,40 \mathrm{~g} / \mathrm{g}$, derajat putih 69,54\%, dan rendemen $39,24 \%$. Pembuatan tepung juga dilakukan oleh Dianty (2017) menggunakan umbi ganyong dengan alat pengering cabinet dryer pada suhu $60^{\circ} \mathrm{C}$ selama 7 jam dan menghasilkan tepung umbi ganyong dengan kadar abu 3,67 \%, kadar protein 0,782 \%, kadar lemak 2,196\%, dan kadar karbohidrat 89,252 \%. Menurut Yuniarti dkk (2013), pengaturan suhu dan lama pengeringan sangat mempengaruhi mutu bahan yang dikeringkan. Semakin tinggi suhu pengeringan dan semakin lama waktu pengeringan dapat mempengaruhi mutu produk yang dihasilkan.

\section{BAHAN DAN METODE}

\section{Alat dan Bahan}

Alat-alat yang digunakan pada penelitian ini adalah timbangan digital, baskom, cabinet dryer, slicer, blender, pisau stainlees steel, ayakan 80 mesh, kertas saring, timbangan analitik, loyang, kemasan alumunium foil kombinasi, cawan porselen, oven, desikator, tungku listrik, tabung reaksi, rak tabung rekasi, blanko, water bath, gelas beker, pipet, tisu, label, Atomic Absorption Spectrophotometry, colorimeter, dan erlenmeyer.

Bahan yang digunakan dalam pelaksanaan penelitian ini adalah talas belitung segar berumur 10-12 bulan yang diperoleh dari Desa Batu Mekar Kecamatan Lingsar Kabupaten Lombok Barat, air, aquades, $\quad \mathrm{NaCl}, \mathrm{NaOH}, \quad$ reagensia Arsenomolibdat, $\mathrm{H}_{2} \mathrm{SO}_{4}, \mathrm{~K}_{2} \mathrm{SO}_{4}, \mathrm{HCl}$, alkohol, dan eter.

\section{Metode}

Metode yang digunakan pada penelitian ini adalah metode eksperimental di Laboratorium. Rancangan percobaan yang digunakan adalah rancangan faktorial yang terdiri dari 2 faktor, yaitu lama perendaman dalam larutan $\mathrm{NaCl}(\mathrm{L})$ terdiri dari 3 aras yaitu lama perendaman 0 menit (L1), 30 menit (L2), 60 menit ( $L 3)$ dan lama pengeringan $(P)$ terdiri
ISSN: 2443-1095

dari 3 aras yaitu lama pengeringan 3 jam (P1), 4 jam (P2), dan 5 jam (P3). Masing-masing aras dari kedua faktor dikombinasikan sehingga diperoleh 9 kombinasi perlakuan yaitu: L1P1, L1P2, L1P3, L2P1, L2P2, L2P3. L3P1， L3P2, dan L3P3. Masing-masing kombinasi perlakuan diulang 3 kali, sehingga diperoleh 27 unit percobaan. Hasil pengamatan dianalisa dengan analisa keragaman (analysis of variance) pada taraf nyata $5 \%$. Apabila terdapat beda nyata, maka akan diuji lanjut menggunakan uji lanjut Duncan Multiple Range Test (DMRT) pada taraf 5\%.

\section{Pelaksanaan Penelitian \\ Pembuatan Tepung Talas Belitung}

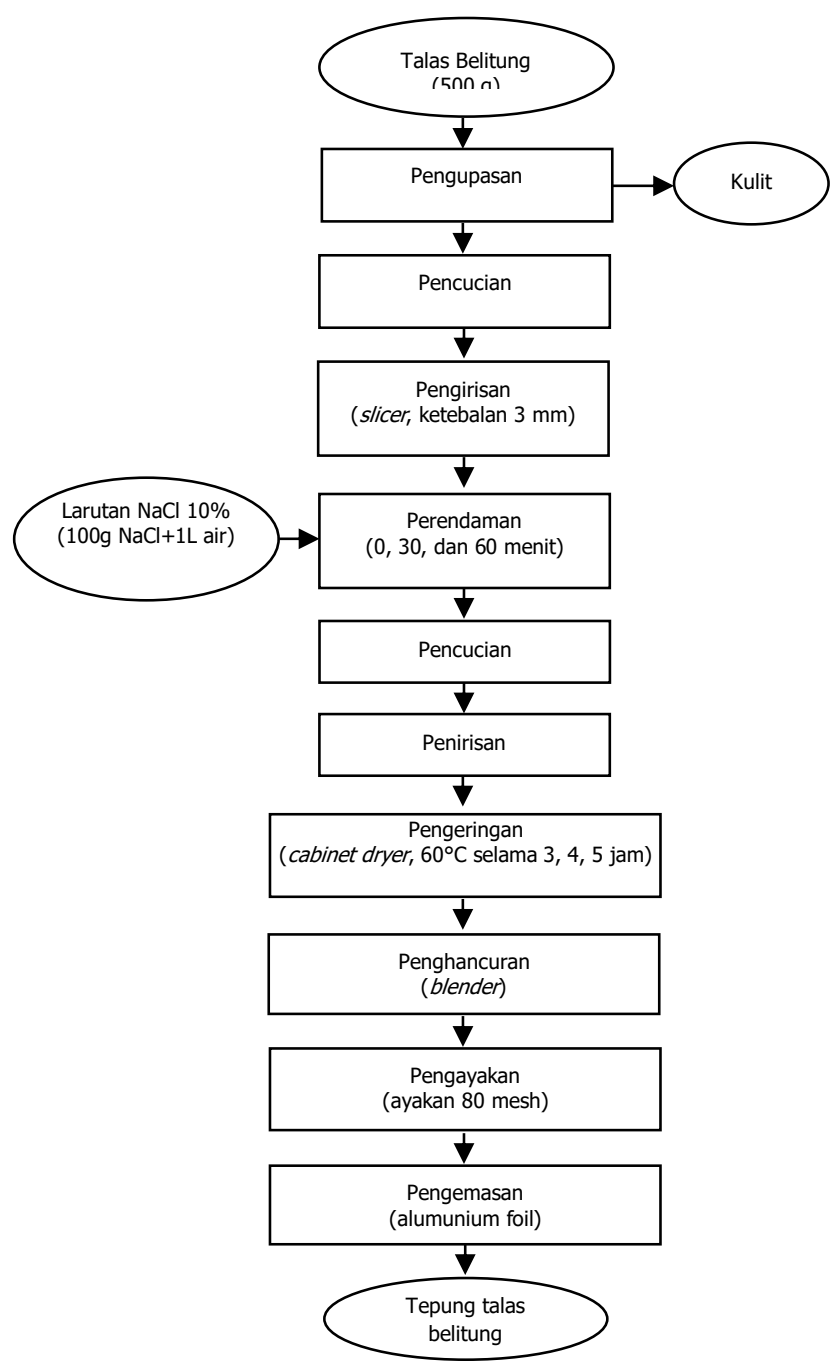

Gambar 1. Pembuatan Tepung Talas Belitung (Sumber: modifikasi penelitian Mayasari (2010) dan Dianty (2017)) 


\section{HASIL DAN PEMBAHASAN}

\section{Analisa Bahan Baku}

Bahan baku utama yang digunakan adalah umbi talas belitung yang berumur 1012 bulan. Hasil analisa kimia umbi talas belitung dapat dilihat pada Tabel 1 .

Tabel 1. Hasil Pengamatan Analisis Kimia Umbi Talas Belitung

\begin{tabular}{ll}
\hline \multicolumn{1}{c}{ Parameter Kimia } & $\begin{array}{c}\text { Umbi Talas } \\
\text { Belitung }\end{array}$ \\
\hline Kadar Air (\%) & 69,66 \\
Kadar Abu (\%) & 1,00 \\
Kadar Pati (\%) & 21,98 \\
Kadar Kalsium Oksalat (mg/100g) & $1.586,25$ \\
Kadar Serat Kasar (\%) & 0,82 \\
\hline
\end{tabular}

Hasil analisa keragaman pengaruh lama perendaman dalam larutan $\mathrm{NaCl}$ dan lama pengeringan terhadap parameter fisik dan kimia tepung talas belitung dapat dilihat pada Tabel 2 dan Tabel 3.

Tabel 2. Hasil ANOVA Parameter Kimia Tepung Talas Belitung

\begin{tabular}{|c|c|c|c|}
\hline \multirow[b]{2}{*}{$\begin{array}{c}\text { Parameter } \\
\text { Kimia }\end{array}$} & \multicolumn{3}{|c|}{ Signifikansi *) } \\
\hline & $\begin{array}{c}\text { Lama Perendama } \\
\text { dalam Larutan } \\
\mathrm{NaCl}(\mathrm{L})\end{array}$ & $\begin{array}{c}\text { Lama } \\
\text { Pengeringan } \\
\text { (P) }\end{array}$ & $\begin{array}{c}\text { Interaksi } \\
\mathbf{L} * \mathbf{P}\end{array}$ \\
\hline Kadar Air & $\mathrm{S}$ & $\mathrm{S}$ & NS \\
\hline Kadar Abu & $\mathrm{S}$ & $\mathrm{S}$ & NS \\
\hline $\begin{array}{l}\text { Kadar Pati } \\
\text { Kadar }\end{array}$ & $\mathrm{S}$ & $\mathrm{S}$ & NS \\
\hline $\begin{array}{l}\text { Kalsium } \\
\text { Oksalat }\end{array}$ & $S$ & $\mathrm{~S}$ & $\mathrm{~S}$ \\
\hline $\begin{array}{l}\text { Kadar Serat } \\
\text { Kasar }\end{array}$ & NS & $S$ & NS \\
\hline
\end{tabular}

Tabel 3. Hasil ANOVA Parameter Fisik Tepung Talas Belitung

\begin{tabular}{lccc}
\hline \multirow{2}{*}{$\begin{array}{c}\text { Parameter } \\
\text { Fisik }\end{array}$} & $\begin{array}{c}\text { Lama Perendaman } \\
\text { dalam Larutan } \\
\text { NaCl (L) }\end{array}$ & $\begin{array}{c}\text { Lama } \\
\text { Pengeringan } \\
\text { (P) }\end{array}$ & $\begin{array}{c}\text { Interaksi } \\
\text { L*P }\end{array}$ \\
\hline $\begin{array}{l}\text { Rendemen } \\
\text { Densitas }\end{array}$ & $\mathrm{S}$ & $\mathrm{S}$ & $\mathrm{NS}$ \\
Kamba & $\mathrm{S}$ & $\mathrm{S}$ & $\mathrm{NS}$ \\
$\begin{array}{l}\text { Warna } \\
\text { Nilai L* }\end{array}$ & $\mathrm{S}$ & $\mathrm{NS}$ & $\mathrm{NS}$ \\
\hline $\begin{array}{l}\text { Keterangan: } \mathrm{S}=\text { Signifikan (berbeda nyata), NS = Non } \\
\text { Signifikan (tidak berbeda nyata), *) }=\text { Taraf Nyata 5\% }\end{array}$ &
\end{tabular}

\section{Kadar Air}

Hasil analisis keragaman pada taraf 5\% (Tabel 2) menunjukkan bahwa lama
ISSN: 2443-1095

perendaman dalam larutan $\mathrm{NaCl}$ memberikan pengaruh yang berbeda nyata terhadap kadar air tepung talas belitung. Pengaruh lama perendaman dalam larutan $\mathrm{NaCl}$ terhadap kadar air tepung talas belitung dapat dilihat pada Gambar 2 .

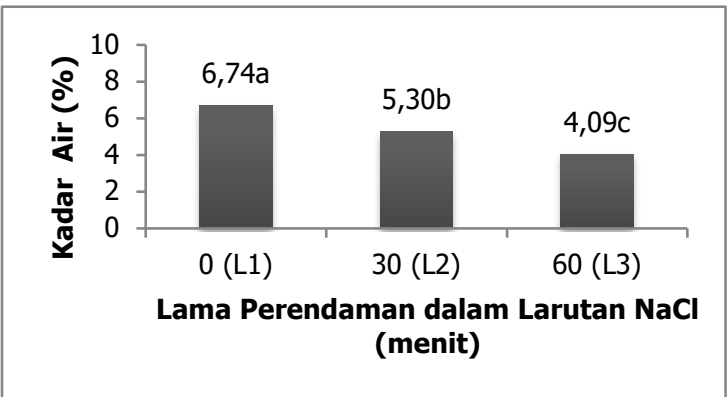

Gambar 2. Pengaruh Lama Perendaman dalam Larutan $\mathrm{NaCl}$ terhadap Kadar Air Tepung Talas Belitung

Kadar air awal umbi talas belitung sebelum diberi perlakuan sebesar 69,66\%, setelah diberi perlakuan perendaman dalam larutan $\mathrm{NaCl}$ rerata kadar air tepung talas belitung berkisar antara 4,09\% - 6,74\% (Gambar 2). Semakin lama perendaman dalam larutan $\mathrm{NaCl}$ menghasilkan kadar air tepung talas belitung semakin rendah. Hal ini diduga disebabkan karena larutan $\mathrm{NaCl}$ yang digunakan dalam perendaman umbi talas belitung menyebabkan terjadi proses osmosis dimana larutan $\mathrm{NaCl}$ yang bersifat higroskopis akan menyerap dan mengeluarkan air dari umbi talas belitung. Sesuai dengan pendapat Witono, et al., (2013) menyatakan bahwa garam memiliki tekanan osmotik yang tinggi (hipertonik) sehingga dapat menarik air dari dalam bahan keluar.

Perlakuan lama pengeringan juga memberikan pengaruh yang berbeda nyata terhadap kadar air tepung talas belitung. Pengaruh lama pengeringan terhadap kadar air tepung talas belitung dapat dilihat pada Gambar 3.

Gambar 3 menunjukkan bahwa semakin lama waktu pengeringan maka kadar air tepung talas belitung semakin rendah. Hal ini disebabkan karena semakin lama suatu bahan kontak langsung dengan panas, maka semakin banyak air yang 
Versi Online:

http://www.profood.unram.ac.id/index.php/profood e-ISSN: 2443-3446

teruapkan. Sesuai dengan pendapat Lubis (2008) menyatakan bahwa lama pengeringan berpengaruh terhadap kadar air, hal ini dikarenakan pengeringan yang cukup lama akan menyebabkan jumlah air yang teruapkan lebih banyak sehingga kadar air dalam bahan tepung berkurang. Berdasarkan hasil pengamatan, kadar air tepung talas belitung yang dihasilkan dari semua perlakuan memenuhi syarat SNI kadar air tepung singkong yaitu maksimal sebesar $12 \%$ dan batas kadar air minimum dimana mikroba masih dapat tetap tumbuh adalah $14-15 \%$ (Fardiaz, 1986).

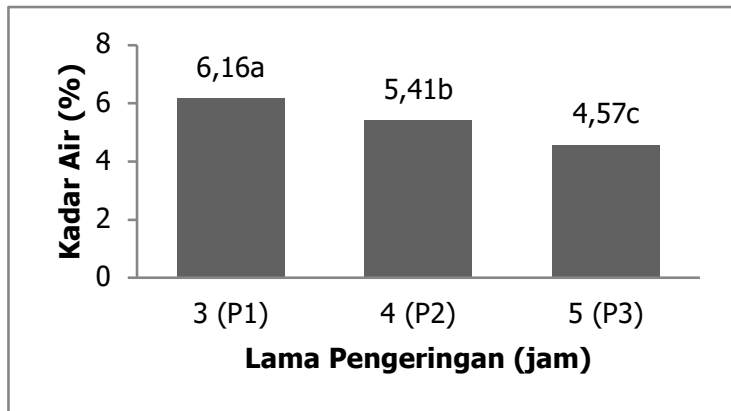

Gambar 3. Pengaruh Lama Pengeringan terhadap Kadar Air Tepung Talas Belitung

\section{Kadar Abu}

Hasil analisis keragaman pada taraf 5\% (Tabel 2) menunjukkan bahwa lama perendaman dalam larutan $\mathrm{NaCl}$ memberikan pengaruh yang berbeda nyata terhadap kadar abu tepung talas belitung. Adapun pengaruh lama perendaman dalam larutan $\mathrm{NaCl}$ terhadap kadar abu tepung talas belitung dapat dilihat pada Gambar 4 .

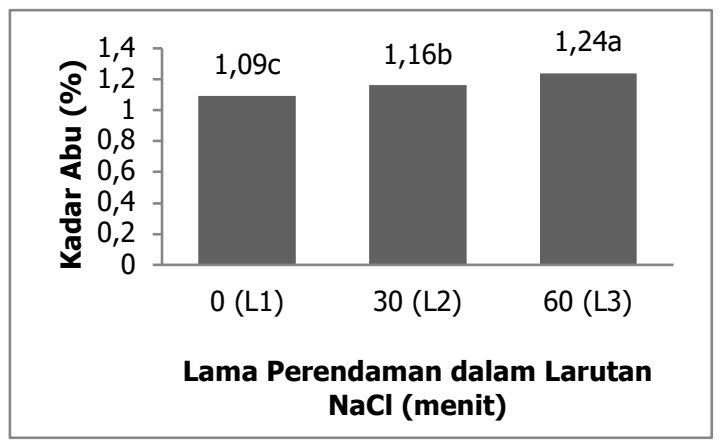

Gambar 4. Pengaruh Lama Perendaman dalam Larutan $\mathrm{NaCl}$ terhadap Kadar Abu Tepung Talas Belitung
Pro Food (Jurnal IImu dan Teknologi Pangan)

Vol 5 No. 1 Mei 2019

ISSN: 2443-1095

Kadar abu awal umbi talas belitung sebelum diberi perlakuan sebesar 1,00\%, setelah diberi perlakuan perendaman dalam larutan $\mathrm{NaCl}$ rerata kadar abu tepung talas belitung berkisar antara 1,09\% - 1,24\% (Gambar 4). Perendaman dalam larutan $\mathrm{NaCl}$ 60 menit (L3) menghasilkan kadar abu lebih tinggi dibandingkan perendaman selama 0 menit (L1) dan 30 menit (L2). Hal ini diduga disebabkan karena perendaman dalam larutan $\mathrm{NaCl}$ menyebabkan terjadinya akumulasi mineral natrium dan klorida pada sampel perlakuan, sehingga semakin lama proses perendaman maka semakin banyak mineral yang masuk ke dalam umbi dan menyebabkan kadar abu tepung talas belitung meningkat. Desniar, et al., (2009) menyatakan bahwa garam mengandung mineral seperti natrium dan klorida. Selain itu, terjadinya proses osmosis dimana larutan $\mathrm{NaCl}$ yang bersifat higroskopis akan menyerap dan mengeluarkan air dari umbi talas belitung lalu sebagian padatan dalam larutan $\mathrm{NaCl}$ akan masuk ke dalam umbi melalui proses difusi.

Perakuan lama pengeringan juga memberikan pengaruh yang berbeda nyata terhadap kadar abu tepung talas belitung. Pengaruh lama pengeringan terhadap kadar abu tepung talas belitung dapat dilihat pada Gambar 5.

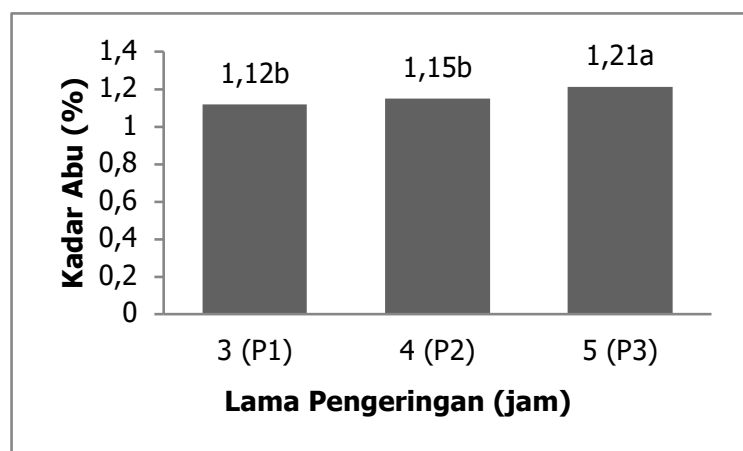

\section{Gambar 5. Pengaruh Lama Pengeringan terhadap Kadar Abu Tepung Talas Belitung}

Gambar 5 menunjukkan bahwa semakin lama waktu pengeringan maka kadar abu tepung talas belitung semakin meningkat. Hal ini diduga disebabkan karena semakin lama waktu pengeringan maka 
Versi Online:

http://Www.profood. unram.ac.id/index.php/profood e-ISSN: 2443-3446

semakin banyak air yang teruapkan sehingga kandungan non mineral semakin meningkat. Sesuai dengan pendapat Erni, et al., (2018) menyatakan bahwa kadar abu tepung umbi talas yang dihasilkan dipengaruhi oleh faktor suhu dan lama pengeringan. Semakin lama dan semakin tinggi suhu pengeringan yang digunakan akan meningkatkan kadar abu, dikarenakan kadar air yang keluar dari dalam bahan semakin besar. Berdasarkan hasil pengamatan, kadar abu tepung talas belitung yang dihasilkan dari semua perlakuan memenuhi syarat SNI kadar abu tepung singkong yaitu maksimal sebesar $1,5 \%$.

\section{Kadar Pati}

Hasil analisis keragaman pada taraf 5\% (Tabel 2) menunjukkan bahwa lama perendaman dalam larutan $\mathrm{NaCl}$ memberikan pengaruh yang berbeda nyata terhadap kadar pati tepung talas belitung. Adapun pengaruh lama perendaman dalam larutan $\mathrm{NaCl}$ terhadap kadar pati tepung talas belitung dapat dilihat pada Gambar 6 .

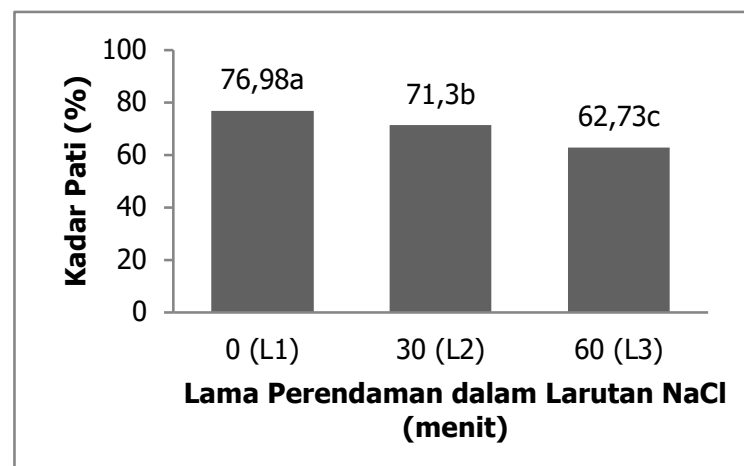

Gambar 6. Pengaruh Lama Perendaman dalam Larutan $\mathrm{NaCl}$ terhadap Kadar Pati Tepung Talas Belitung

Kadar pati awal umbi talas belitung sebelum diberi perlakuan sebesar 21,98\%, setelah diberi perlakuan perendaman dalam larutan $\mathrm{NaCl}$ rerata kadar pati tepung talas belitung berkisar antara 62,73\% - 76,98\% (Gambar 6). Semakin lama perendaman dalam larutan $\mathrm{NaCl}$ maka kadar pati tepung talas belitung semakin rendah. Hal ini diduga disebabkan karena sebagian pati mengendap dalam larutan dan akhirnya ikut terbuang
Pro Food (Jurnal IImu dan Teknologi Pangan)

Vol 5 No. 1 Mei 2019

ISSN: 2443-1095

bersama air rendaman. Hal ini sesuai dengan pendapat Zuhro, et al., (2015) menyatakan bahwa penurunan kadar pati disebabkan karena saat proses pengolahan yaitu pada saat chips kimpul dicuci setelah direndam dalam aquades menyebabkan sebagian pati mengendap dalam air dan tidak ikut dalam proses penepungan. Mayasari (2010) menyatakan bahwa dengan perlakuan perendaman dalam larutan $\mathrm{NaCl}$ terhadap tepung talas bogor yang dihasilkan kadar pati cenderung menurun dibandingkan kadar pati pada tepung tanpa perlakuan.

Perlakuan lama pengeringan juga memberikan pengaruh yang berbeda nyata terhadap kadar pati tepung talas belitung. Pengaruh lama pengeringan terhadap kadar pati tepung talas belitung dapat dilihat pada Gambar 7.

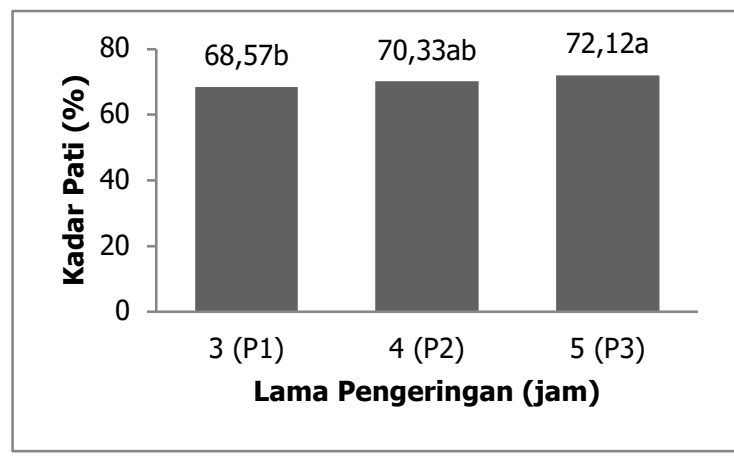

Gambar 7. Pengaruh Lama Pengeringan terhadap Kadar Pati Tepung Talas Belitung

Gambar 7 menunjukkan bahwa semakin lama waktu pengeringan maka kadar pati tepung talas belitung semakin meningkat karena semakin banyak air yang teruapkan kandungan bahan seperti karbohidrat akan lebih terkonsentrasi. Sesuai dengan pendapat Erni, et al., (2018) menyatakan bahwa kadar pati tepung umbi talas yang dihasilkan dipengaruhi oleh faktor suhu dan lama pengeringan. Hal ini diduga karena selama pengeringan kandungan karbohidrat bahan semakin meningkat dengan semakin rendahnya kandungan air dalam bahan pangan. Berdasarkan hasil pengamatan, kadar pati tepung talas belitung hanya perlakuan L1 (lama perendaman dalam larutan $\mathrm{NaCl} 0$ menit) 
Versi Online:

http://www.profood.unram.ac.id/index.php/profood e-ISSN: 2443-3446

memenuhi syarat SNI pati tepung singkong yaitu minimal sebesar $75 \%$.

\section{Kadar Kalsium Oksalat}

Hasil analisis keragaman pada taraf 5\% (Tabel 2) menunjukkan bahwa interaksi lama perendaman dalam larutan $\mathrm{NaCl}$ dengan lama pengeringan memberikan pengaruh yang berbeda nyata terhadap kadar kalsium oksalat tepung talas belitung. Interaksi pengaruh lama perendaman dalam larutan $\mathrm{NaCl}$ dengan lama pengeringan terhadap kadar kalsium oksalat tepung talas belitung dapat dilihat pada Gambar 8 .

Kadar kalsium oksalat umbi talas belitung sebelum diberi perlakuan sebesar $1.586 \mathrm{mg} / 100 \mathrm{~g}$, setelah diberi perlakuan perendaman dan pengeringan rerata kadar kalsium oksalat tepung talas belitung berkisar antara 337 - $1.159 \mathrm{mg} / 100 \mathrm{~g}$ (Gambar 8). Dari hasil penelitian ini kadar kalsium oksalat tertinggi terdapat pada perlakuan L1P1 (lama perendaman dalam larutan $\mathrm{NaCl} 0$ menit dan lama pengeringan 3 jam) sebesar $1.159 \mathrm{mg} / 100 \mathrm{~g}$ sedangkan kadar kalsium oksalat terendah terendah yaitu pada perlakuan L3P3 (lama perendaman dalam larutan $\mathrm{NaCl} 60$ menit dan lama pengeringan 5 jam) sebesar 337 $\mathrm{mg} / 100 \mathrm{~g}$.

Gambar 8 menunjukkan bahwa semakin lama perendaman dalam larutan $\mathrm{NaCl}$ dan semakin lama pengeringan maka
Pro Food (Jurnal IImu dan Teknologi Pangan)

Vol 5 No. 1 Mei 2019

ISSN: 2443-1095

kadar kalsium oksalat tepung talas belitung semakin menurun. Hal ini diduga disebabkan karena perendaman dalam larutan $\mathrm{NaCl}$ dapat mereduksi kalsium oksalat pada umbi talas belitung. Hal ini sesuai dengan pendapat Mayasari (2010) yang menyatakan banhwa perendaman pada larutan garam $(\mathrm{NaCl})$ menunjukkan nilai persentase reduksi oksalat yang cenderung meningkat seiring dengan peningkatan konsentrasi larutan, begitu pula pada proses lama perendaman memiliki nilai persentase reduksi yang cenderung meningkat dengan semakin lamanya waktu perendaman.

Selain itu, semakin lama waktu pengeringan maka semakin banyak kalsium oksalat yang tereduksi. Metode fisis yang paling sering digunakan untuk mengurangi atau menghilangkan rasa gatal akibat kandungan kalsium oksalat adalah dengan pemanasan (Smith, 1997). Pemanasan dilakukan melalui penjemuran, pemasakan (Lee, 1999); perebusan, perendaman dalam air hangat, pemanggangan (Iwuoha dan Klau, 1994); dan pengeringan (Nur, 1986). Berdasarkan hasil pengamatan, kadar kalsium oksalat tepung talas belitung yang dihasilkan dari semua perlakuan telah memenuhi persyaratan batas aman konsumsi kalsium oksalat bagi orang dewasa yaitu sebesar 0,60-1,25 g (Knudsen, et al., 2008).

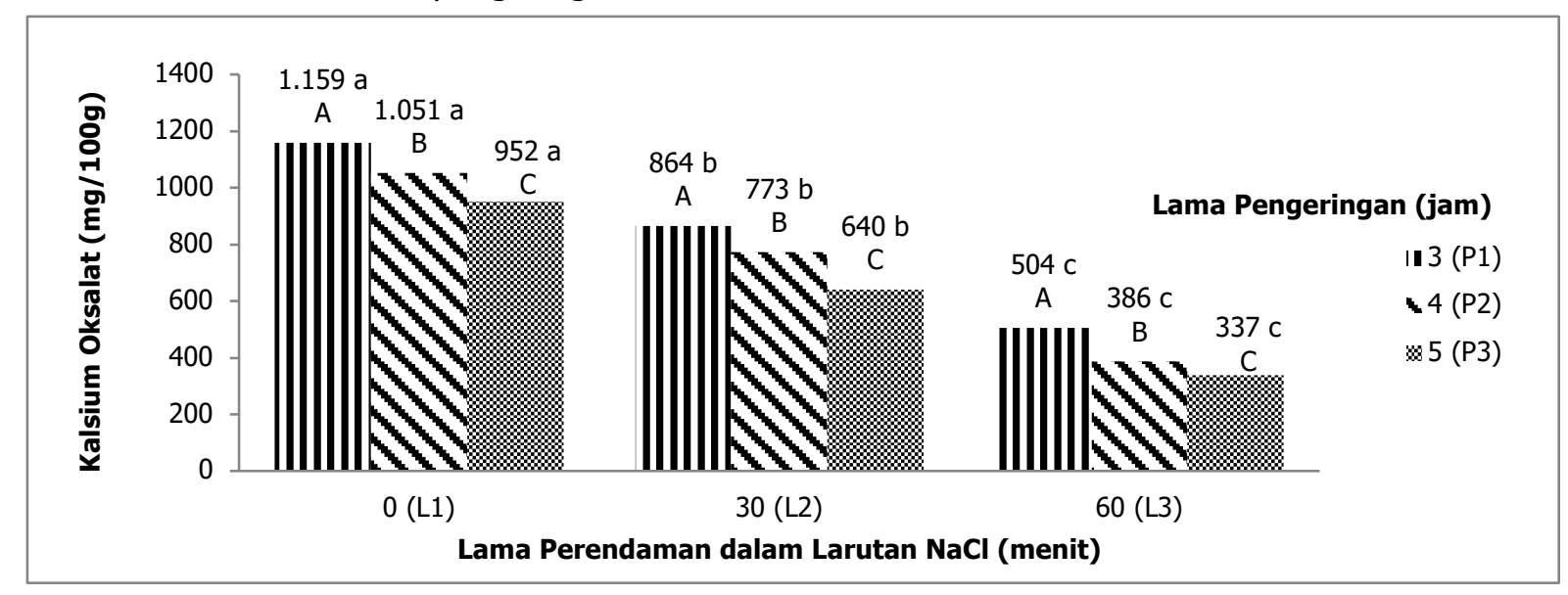

Gambar 8. Interaksi Pengaruh Lama Perendaman dalam Larutan $\mathrm{NaCl}$ dengan Lama Pengeringan Terhadap Kadar Kalsium Oksalat Tepung Talas Belitung 


\section{Kadar Serat Kasar}

Hasil analisis keragaman pada taraf 5\% (Tabel 2) menunjukkan bahwa lama pengeringan memberikan pengaruh yang berbeda nyata terhadap kadar serat kasar tepung talas belitung. Pengaruh lama pengeringan terhadap kadar serat kasar tepung talas belitung dapat dilihat pada Gambar 9.

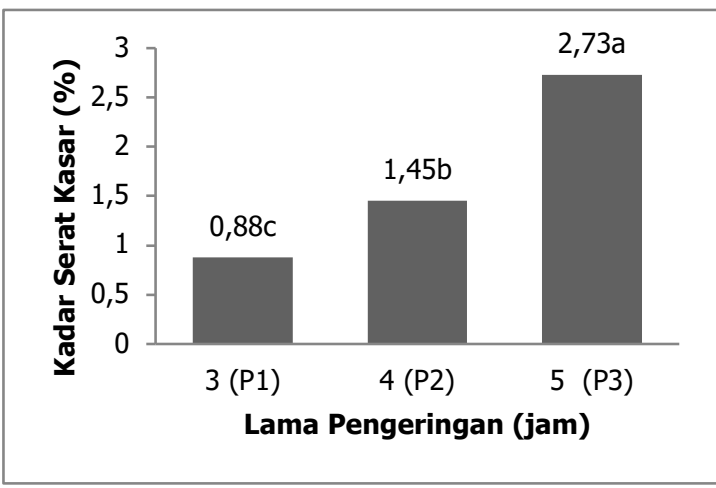

Gambar 9. Pengaruh Lama Pengeringan terhadap Kadar Serat Kasar Tepung Talas Belitung

Kadar serat kasar umbi talas belitung sebelum diberi perlakuan sebesar $0,82 \%$, setelah diberi perlakuan pengeringan rerata kadar serat kasar tepung talas belitung berkisar antara 0,88\% - 2,73\% (Gambar 9). Semakin lama waktu pengeringan maka kadar serat kasar tepung talas belitung semakin meningkat. Hal ini diduga karena semakin lama waktu pengeringan kadar air semakin banyak teruapkan sehingga serat kasar akan lebih terkonsentrasi. Sesuai dengan pendapat Dianty (2017) menyatakan bahwa bahwa semakin lama pengeringan yang dilakukan maka kadar serat produk semakin meningkat. Selain itu, Ekky, et al., (2015) juga menyatakan dalam penelitiannya tentang pengaruh waktu dan lama pemanasan terhadap kadar serat kasar yang menunjukan bahwa semakin tinggi suhu dan lama pemanasan akan menyebabkan semakin tinggi pula serat kasarnya. Berdasarkan hasil pengamatan, kadar serat kasar tepung talas belitung yang dihasilkan dari semua perlakuan telah memenuhi syarat SNI serat kasar tepung singkong maksimal sebesar $4 \%$.

\section{Rendemen}

Hasil analisis keragaman pada taraf 5\% (Tabel 3) menunjukkan bahwa lama perendaman dalam larutan $\mathrm{NaCl}$ memberikan pengaruh yang berbeda nyata terhadap rendemen tepung talas belitung. Adapun pengaruh lama perendaman dalam larutan $\mathrm{NaCl}$ terhadap rendemen tepung talas belitung dapat dilihat pada Gambar 10 .

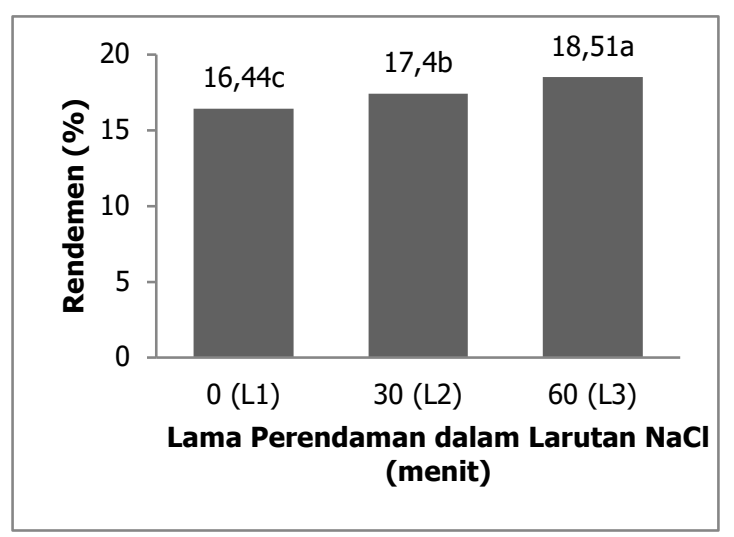

Gambar 10. Pengaruh Lama Perendaman dalam Larutan $\mathrm{NaCl}$ terhadap Rendemen Tepung Talas Belitung

Rendemen tepung talas belitung setelah diberi perlakuan perendaman rerata berkisar antara 16,44\% - 18,51\% (Gambar 10). Semakin lama perendaman maka rendemen tepung talas belitung semakin meningkat. Hal ini diduga disebabkan karena perendaman dalam larutan $\mathrm{NaCl}$ terhadap umbi talas belitung menambah massa tepung yang dihasilkan. Sesuai dengan pendapat Putri dan Suharnas (2010) yang menyatakan bahwa konsentrasi garam yang digunakan dalam perendaman umbi gadung berpengaruh nyata terhadap rendemen umbi gadung. Hal ini disebabkan adanya proses osmosis dimana larutan garam yang bersifat higroskopis akan menyerap dan mengeluarkan air dari umbi gadung lalu sebagian padatan dalam larutan garam akan masuk ke dalam umbi melalui proses difusi sehingga menambah massa umbi gadung.

Perlakuan lama pengeringan juga memberikan pengaruh yang berbeda nyata terhadap rendemen tepung talas belitung. Pengaruh lama pengeringan terhadap 
Versi Online:

http://Www.profood. unram.ac.id/index.php/profood e-ISSN: 2443-3446

rendemen tepung talas belitung dapat dilihat pada Gambar 11.

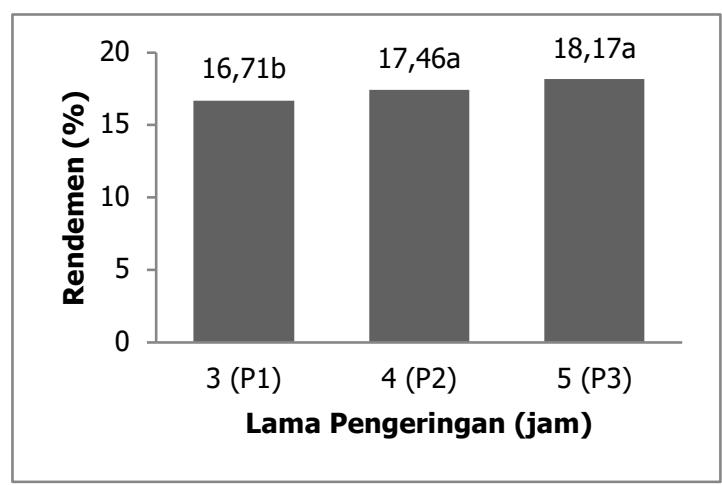

Gambar 11. Pengaruh Lama Pengeringan terhadap rendemen Tepung Talas Belitung

Gambar 11 menunjukkan bahwa semakin lama waktu pengeringan maka rendemen tepung talas belitung semakin meningkat karena pengeringan selama 5 jam menghasilkan chips talas belitung yang lebih kering dibandingkan pengeringan selama 3 jam sehingga pada saat proses penepungan dan pengayakan pengeringan 5 jam lebih banyak menghasilkan tepung talas belitung. Menurut (Agus, 2010) kadar air tepung yang dihasilkan pada bahan dapat mempengaruhi nilai rendemen tepung. Rizal, (2013) menyatakan bahwa semakin lama pengeringan yang digunakan maka rendemen yang dihasilkan semakin rendah, hal ini disebabkan semakin lama pengeringan maka terjadi penguapan air yang teruapkan semakin besar.

\section{Densitas Kamba}

Hasil analisis keragaman pada taraf 5\% (Tabel 3) menunjukkan bahwa lama perendaman dalam larutan $\mathrm{NaCl}$ memberikan pengaruh yang berbeda nyata terhadap densitas kamba tepung talas belitung. Pengaruh lama perendaman dalam larutan $\mathrm{NaCl}$ dan lama pengeringan terhadap densitas kamba tepung talas belitung dapat dilihat pada Gambar 12.

Densitas kamba tepung talas belitung setelah diberi perlakuan perendaman rerata berkisar antara 0,69 $-0,74 \mathrm{~g} / \mathrm{ml}$ (Gambar 12). Semakin lama perendaman maka
ISSN: 2443-1095

densitas kamba tepung talas belitung semakin menurun. Hal ini diduga karena perendaman dalam larutan $\mathrm{NaCl}$ terhadap umbi talas belitung menyebabkan sebagian pati yang memiliki berat molekul tinggi mengendap dalam larutan dan ikut terbuang bersama air rendaman, sehingga densitas kamba tepung talas belitung yang dihasilkan rendah. Sesuai dengan pendapat Zuhro, et al., (2015) yang menyatakan bahwa kandungan pati pada tepung kimpul berpengaruh terhadap densitas tepung yang dihasilkan. Bahan pangan yang memiliki densitas kamba tinggi menunjukkan kepadatan gizi yang tinggi juga. Bhatacharya dan Prakash (1994) menyatakan bahwa kadar pati yang tinggi pada tepung menyebabkan densitas kamba meningkat. Hal ini disebabkan kadar pati memiliki berat molekul yang tinggi sehingga menghasilkan densitas yang tinggi pula.

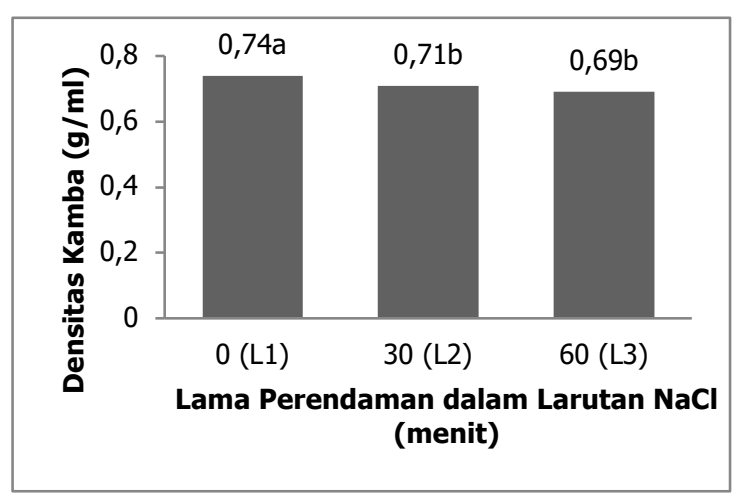

Gambar 12. Pengaruh Lama Perendaman dalam Larutan $\mathrm{NaCl}$ terhadap Densitas Kamba Tepung Talas Belitung

Perlakuan lama pengeringan juga memberikan pengaruh yang berbeda nyata terhadap densitas kamba tepung talas belitung. Pengaruh lama pengeringan terhadap densitas kamba dapat dilihat pada Gambar 13.

Gambar 13 menunjukkan bahwa semakin lama waktu pengringan maka densitas kamba tepung talas belitung semakin meningkat karena air yang teruapkan lebih banyak sehingga bahan padatan yang memiliki berat molekul yang besar seperti karbohidrat akan lebih 
Versi Online:

http://Www.profood. unram.ac.id/index.php/profood e-ISSN: 2443-3446

terkonsentrasi. Menurut Muchtadi dan Ayustaningwarno (2010), mengemukakan bahwa dengan mengurangi kadar airnya, bahan pangan akan mengandung senyawasenyawa seperti karbohidrat, protein dan mineral dalam konsentrasi yang lebih tinggi. Sesuai dengan pendapat Erni, et al., (2018) menyatakan bahwa kadar pati tepung umbi talas yang dihasilkan dipengaruhi oleh faktor suhu dan lama pengeringan. Hal ini diduga karena selama pengeringan kandungan karbohidrat bahan semakin meningkat dengan semakin rendahnya kandungan air dalam bahan pangan. Dengan meningkatnya kadar pati akibat pengeringan maka meningkat pula densitas kamba yang dihasilkan.

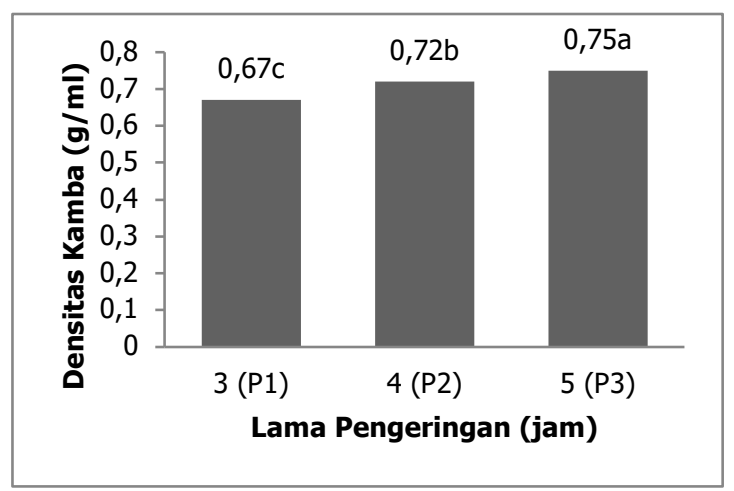

Gambar 13. Pengaruh Lama Pengeringan terhadap Densitas Kamba Tepung Talas Belitung

\section{Warna Nilai L*}

Hasil analisis keragaman pada taraf 5\% (Tabel 3) menunjukkan bahwa lama perendaman dalam larutan $\mathrm{NaCl}$ memberikan pengaruh yang berbeda nyata terhadap warna nilai $L^{*}$ tepung talas belitung. Pengaruh lama perendaman dalam larutan $\mathrm{NaCl}$ terhadap warna nilai $\mathrm{L}^{*}$ tepung talas belitung dapat dilihat pada Gambar 14 .

Warna nilai $L^{*}$ tepung talas belitung setelah diberi perlakuan perendaman dalam larutan $\mathrm{NaCl}$ rerata berkisar antara 86,40 93,53 (Gambar 14). Semakin lama perendaman dalam larutan $\mathrm{NaCl}$ maka warna tepung talas belitung semakin cerah. Hal ini diduga disebabkan karena larutan $\mathrm{NaCl}$ mengandung klorin yang dapat mempertahankan warna tepung yang
ISSN: 2443-1095

dihasilkan. Mayasari (2010) menyatakan bahwa perendaman dalam larutan $\mathrm{NaCl}$ yang menghasilkan warna tepung lebih putih dapat disebabkan oleh salah satu sifat senyawa natrium yang berfungsi sebagai garam natrium dari asam lemak yang mampu mengikat kotoran, sehingga air rendaman akan bebas dari kotoran dan menyebabkan sampel hasil perendaman pun memiliki tingkat kebersihan yang lebih tinggi. Natrium klorida merupakan bahan baku yang digunakan untuk menghasilkan klorin. Klorin merupakan salah satu unsur yang berfungsi sebagai bahan pemutih.

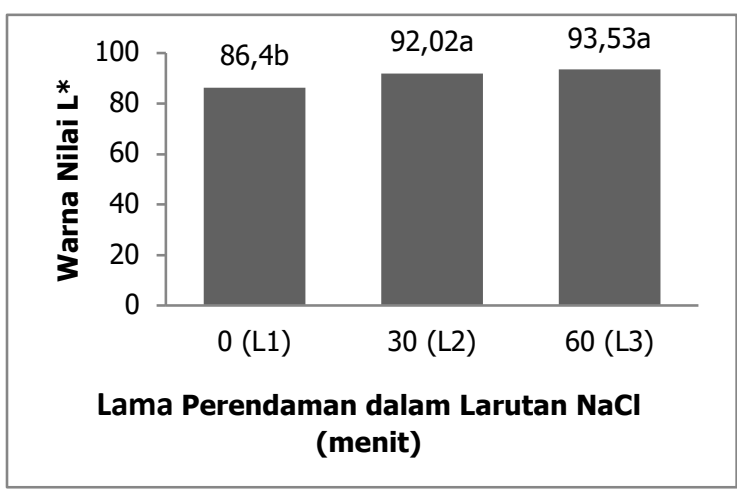

Gambar 14. Pengaruh Lama Perendaman dalam Larutan $\mathrm{NaCl}$ terhadap Warna Nilai L* Tepung Talas Belitung

\section{KESIMPULAN}

Perlakuan lama perendaman dalam larutan $\mathrm{NaCl}$ memberikan pengaruh yang berbeda nyata terhadap parameter kimia (kadar air, abu, pati, kalsium oksalat, serat kasar) dan parameter fisik (rendemen, densitas kamba, warna nilai L*). Perlakuan lama pengeringan memberikan pengaruh yang berbeda nyata terhadap parameter kimia (air, abu, pati, kalsium oksalat, serat kasar) dan parameter fisik (rendemen dan densitas kamba). Perlakuan terbaik yaitu lama perendaman dalam larutan $\mathrm{NaCl} 60$ menit dan lama pengeringan 5 jam (L3P3) dengan kadar air 3,56\%, abu $1,31 \%$, pati $64,36 \%$, kalsium oksalat $337,82 \mathrm{mg} / 100 \mathrm{~g}$, serat kasar 2,5\%, rendemen $19,13 \%$, densitas kamba $0,71 \mathrm{~g} / \mathrm{ml}$, dan warna nilai L* 92,28 yang telah memenuhi syarat SNI mutu tepung singkong. 


\section{DAFTAR PUSTAKA}

Agus, S. 2010. Pengaruh Perlakuan Pendahuluan Pada Pembuatan Tepung Ganyong (Canna edulis) terhadap Sifat Fisik dan Amilografi Tepung Yang Dihasilkan. Skripsi. Fakultas Agroindustri. Universitas Mercu Buana Yogyakarta. Yogyakarta.

Almatsier, S. 2010. Prinsip Dasar IImu Gizi. Jakarta: PT Gramedia Pustaka Utama

Bhattacharya, S., M. Prakash. 1994 Extrusion of blends of rice and chick pea flours: A response surface analysis. Journal of Food Engineering 21(3): 315-330.

Desniar, D. Poernomo dan W. Wijatur. 2009. Pengaruh Konsentrasi $\mathrm{HCN}, \mathrm{NaCl}$ dan Bahan Organik pada Umbi Gadung (Dioscorea hispida) sebagai Pakan Ternak. Skripsi. Universitas Indonesia. Jakarta.

Dianty, A. 2017. Pengaruh Jenis Pengeringan dan Lama Pengeringan terhadap Karakteristik Tepung Umbi Ganyong. Tugas Akhir. Program Studi Teknologi Pangan. Fakultas Teknik. Universitas Pasudan. Bandung.

Listiana, E.A., S. Winarsih, T.S. Kusuma. 2015. Suhu dan Waktu Mempengaruhi Kadar Karbohidrat dan Serat Kasar Pada Cookies Tanah Liat dan Rumput Laut Merah (Kappaphycus avareil). Skripsi. Departemen Nutrisi. Fakultas Kedokteran. Universitas Brawijaya. Malang.

Erni, N., Kardiman, R. Fadillah. 2018. Pengaruh Suhu dan Lama Pengeringan terhadap Sifat Kimia dan Organoleptik Tepung Umbi Talas (Colocasia esculanta). Jurnal Pendidikan Teknologi Pertanian 4: 95-105.

Fardiaz, S. 1986. Mikrobiologi Pangan I. Gramedia Pustaka Utama. Jakarta.

Hadriati, D. 2016. Karakteristik Fisik, Kimia dan Fungsional Tepung Kimpul (Xanthosoma sagittifolium) Hasil Fermentasi dan Aplikasinya pada Proses Pembuatan Mie Instan. Skripsi. Universitas Brawijaya. Malang.

Indrasti, D. 2004. Pemanfaatan Tepung Talas Belitung (Xanthosoma sagitifolium) dalam Pembuatan Cookies. Skripsi.
ISSN: 2443-1095

Program Sarjana, Institut Pertanian Bogor. Bogor.

Iwuoha, I.C, and F.A. Klau. 1994. Calcium Oxalate dan Physico-chemical Propertise of Cocoyam (Colocasia esculenta and Xanthosoma sagittifolium) Tuber Flours as Affected by Processing. J.Food Chem 54: 61-66.

Knudsen, I., I. Soborg, F. Eriksen, K. Pilegaard, J. Pederse. 2008. Risk Management and Risk Assesment of Novel Plant Foods: Concepts and Principles. Food and Chemical Toxicology 46(5): 1681-1705.

Koswara, S. 2010. Teknologi Pengolahan Umbi-Umbian. Bogor Agricultural University. Bogor.

Lee, W. 1999. Tropical Root Crops. Southern Illionis University. Illionis.

Lingga P. 1986. Bertanam Ubi-ubian. PT Penebar Swadaya. Jakarta.

Lubis, I.H.. 2008. Pengaruh Suhu dan Lama Pengeringan terhadap Mutu Tepung Pandan. Skripsi:: Universitas Sumatera Utara. Medan.

Mariani, R. 2008. Mencegah Batu Ginjal dan Batu Empedu http://www.indofarma.co.id/index.php [diakses 2 Mei 2018].

Marliana, E. 2011. Karakterisasi Dan Pengaruh Nacl Terhadap Kandungan Oksalat Dalam Pembuatan Tepung Talas Banten. Skripsi. Fakultas Teknologi Pertanian. Institut Pertanian Bogor. Bogor.

Mayasari, N. 2010. Pengaruh Garam dan Asam Pada Pembuatan Tepung Talas Bogor (Colocasia esculenta (L.) Schott). Skripsi. Fakultas Teknologi Pertanian. Institut Pertanian Bogor. Bogor.

Muchtadi, T. dan F. Ayustaningwarno. 2010. Teknologi Proses Pengolahan Pangan. Institut Pertanian Bogor Press. Bogor.

Nur, M. 1986. Tanaman Talas (Colocasia dan beberapa Genus yang lain). Kementrian Pertanian. Jakarta.

Onwuene, IC. 1978. The Tropical Tuber Crops. Jhon Willey and Sons. New York

Purwaningsih, I., Kuswiyanto. 2016. Perbandingan Perendaman Asam Sitrat dan Jeruk Nipis Terhadap Penurunan 
Kadar Kalsium Oksalat pada Talas. Jurnal Vokasi Kesehatan II(1): 89-93.

Putri, J.A.A. dan E. Suharnas. 2010. Pengaruh Perendaman dengan Larutan Garam Terhadap Kandungan Rendemen, Bahan Kering, Serat Kasar dan Bahan Ekstrak Tanpa Nitrogen (BETN) Umbi Gadung (Dioscorea hispida) Sebagai Pakan Ternak. Artikel. Program Studi Peternakan. Fakultas Pertanian. Universitas Muhammadiyah Bengkulu. Bengkulu.

Ridal, S. 2003. Karakteristik sifat Fisiko-Kimia tepung dan pati talas (Colocasia esculenta) dan kimpul (Xanthosoma sp.) dan uji penerimaan a-amilase terhadap patinya. Skripsi. Fakultas Teknologi Pertanian. Institut Pertanian Bogor. Bogor.

Rizal, S. 2013. Pengaruh konsentrasi Natrium Bisulfit dan Suhu Pengeringan Terhadap Sifat Fisik-Kimia Tepung Biji Nangka (Artocarpus heterophyllus). Skripsi. Jurusan Keteknikan Pertanian. Fakultas Teknologi Pertanian. Universitas Brawijaya. Malang.

Smith, D.S. 1997. Processing Vegetables Science and Technology. Technonic Publishing Company Inc. London

Winarno, F.G dan W. Agustinah. 2008. Peran Pangan dan Autism. PT Gramedia Pustaka Utama. Jakarta.

Witono, J.R.B. Y.I.P.A. Miranti dan L. Yuniarti. 2013. Studi Kinetika Osmotik pada Ikan Teri dalam Larutan Biner dan Terner. Lembaga Penelitian dan Pengabdian kepada Masyarakat. Universitas Katolik Prahayangan. Bandung.

Yuniarti, D.W., T.D. Sulistiyati, dan E. Suprayitno. 2013. Pengaruh Suhu Pengeringan Vakum terhadap Kualitas Serbuk Albumin Ikan Gabus (Ophiocephalus striatus). Jurnal THPi Student 1(1): 1-11.

Zuhro, M. Lutfi, M dan Hawa, L. C. 2015. Pengaruh Lama Perendaman dan Suhu Pengeringan terhadap Sifat Fisik - Kimia Tepung Kimpul. Jurnal Bioproses Komoditas Tropis 3(2): 26-32. 